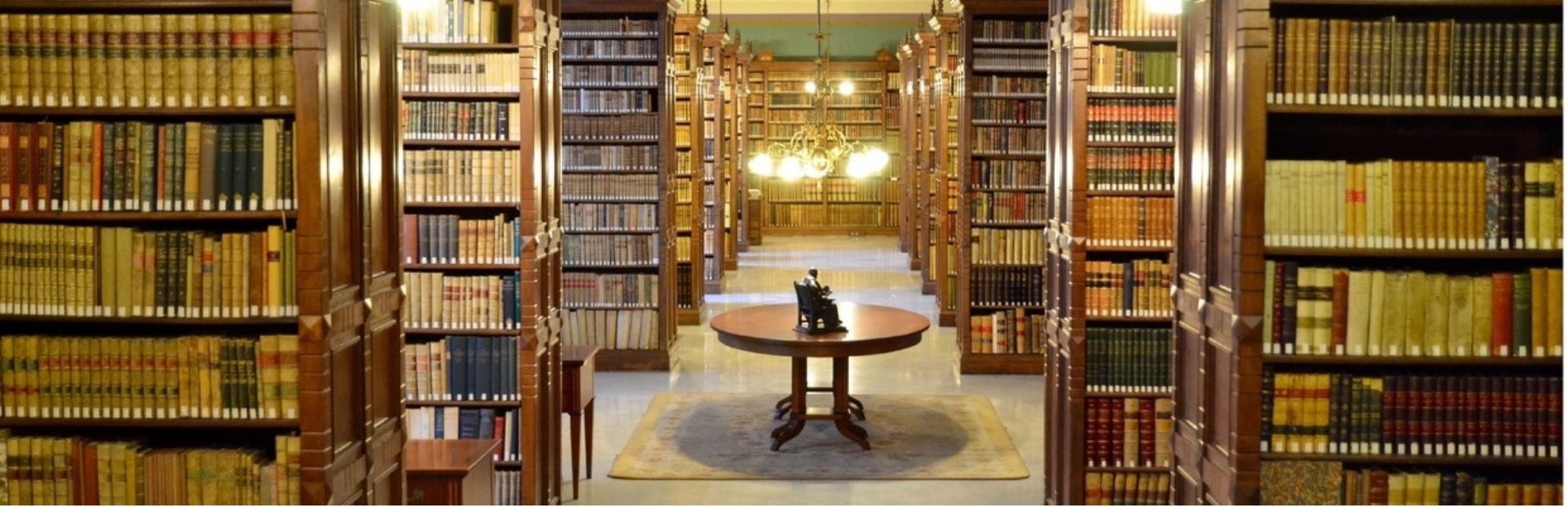

\title{
Editorial Volume 8, Issue 3
}

$\begin{aligned} \text { Authors: } & \text { Stephan Seiler } \\ \text { Submitted: } & \text { 9. August } 2021 \\ \text { Published: } & \text { 10. August } 2021 \\ \text { Volume: } & 8 \\ \text { Issue: } & 4 \\ \text { Affiliation: } & \text { Josha Journal. Freiburg, Germany } \\ \text { Languages: } & \text { English } \\ \text { Keywords: } & \text { Editorial, JOSHA Journal, } 2021 \text { Volume 8, Issue } 3 \\ \text { Categories: } & \text { News and Views } \\ \text { DOI: } & 10.17160 / \text { josha.8.4.776 }\end{aligned}$

Abstract:

The current volume features the full range of the Josha Journal. Students write about their experiences during Covid Lockdown, Nobel Laureate Joachim Frank talks about his scientific career. From the numerous further contributions, we like to advise George M. Weisz, "Once more on the Fate of Intellectuals in Nazi Camps", an impressive report about intellectuals in Auschwitz.

\section{JOSHA Jounmalosemenee Humanities and Arts}




\section{Editorial}

Volume 8, Issue 3

The current volume features the full range of the Josha Journal. Students write about their experiences during Covid Lockdown, Nobel Laureate Joachim Frank talks about his scientific career. From the numerous further contributions, we like to advise George M. Weisz, "Once more on the Fate of Intellectuals in Nazi Camps", an impressive report about intellectuals in Auschwitz.

The Journal again would like to call your attention to the Demetrios Prizes, which will be awarded again this year! This initiative is made possible by the International Academy of Sciences, Humanities and Arts (IASHA e.V.) and the BioThera Roland-Mertelsmann Foundation. For the categories Bachelor, Master and Doctor Thesis we will award three prizes in the fall of 2021 of $500 €$ each. For your chance to win, submit your thesis until August $31^{\text {st }} 2021$ !

Now we hope you enjoy reading the journal.

Dr. Stephan Seiler, Vice President, International Academy of Sciences, Humanities and Arts

\section{Volume 8, Issue 3}

Franziska Buttgereit: Sugar

Vitalis Ugwu: Defining Life in African Igbo Cosmology

Smilla Werle: Wie Gefangene im eigenen Zimmer - It's just like being held Hostage in your own Room

Kelechi Naze: Juxtaposition of Immanuel Kant, Friedrich Nietzsche and Hannah Arendt's Conceptions of Will: It's ethical Implications

Joachim Frank: My early Werdegang in Science: Reflections of a Nobel Laureate

Julika Diener: Früher fand sie es todlangweilig - She used to find it deadly boring

George M. Weisz: Once more on the Fate of Intellectuals in Nazi Camps

Tatiana T. Castañeda: Señales Biológicas Cerebrales y Cognición - Biological Brain Signals and Cognition

Timoteo Marchini: Nubosidad variable - Partially cloudy

Bardha Meka, Vlora Navakazi, Flaka Xërxa Beqiri: Assessment of primary Health Care Facilities in Kosovo using Space Syntax Analysis

Dardan Kocinaj, Antigona Ukehaxhaj, Arben Boshnjaku, Naser Ramadani et al.: Water Quality and Safety of Potable Water Wells in Gjakova Region, Kosovo

Frank Wertheimer: Wiederzuweisung von Personal- und Sachmitteln aus einer Bleibezusage - VGH BadenWürttemberg, Urt. v. 20.04.2020, 9 S 1897/18 - Reallocation of personnel and material Resources

Robert M. Kaplan: The Shrink who Shrunk Himself: The Rise and Fall of Ronnie Laing

Amina Poplata: Evaluation of chloroquine and hydroxychloroquine efficacy on chemotherapy treatment in triple negative breast cancer by continuous live cell imaging 